\title{
Antioxidant, analgesic and anti-inflammatory activities of Leucas cephalotes (Roxb.ex Roth) Spreng
}

\author{
Bhukya Baburao', Anreddy Rama Narsimha Reddy', Gangarapu Kiran², \\ Yellu Narsimha Reddy ${ }^{1}$, Gottumukkala Krishna Mohan ${ }^{1, *}$ \\ ${ }^{I}$ University College of Pharmaceutical Sciences, Kakatiya University, Warangal, India, \\ ${ }^{2} S$. R. College of Pharmacy, Ananthasager, Warangal, India
}

\begin{abstract}
The whole plant of the methanolic extract from Leucas cephalotes was screened for in vitro antioxidant (using the DPPH method), in vivo analgesic (using hot plate test in mice) and anti-inflammatory (using rat paw edema test) activities. The methanolic extract of Leucas cephalotes (MELC) scavenged the DPPH radicals in a dose-dependent manner. The $\mathrm{IC}_{50}$ value to scavenge DPPH radicals was found to be $421.3 \mu \mathrm{g} / \mathrm{ml}$. A significant ( $<<0.0005$ ) analgesic activity was observed at $60 \mathrm{~min}$ with $200 \mathrm{mg} / \mathrm{kg}$, and $400 \mathrm{mg} / \mathrm{kg}$ exhibited maximum activity. The maximum anti-inflammatory response was produced at 3 $\mathrm{hr}$ and $2 \mathrm{hr}$ with doses of 200 and $400 \mathrm{mg} / \mathrm{kg}$, respectively. These results suggest that the methanolic extract from Leucas cephalotes exerts significant analgesic and anti-inflammatory effects, which were comparable with standard drugs.
\end{abstract}

Uniterms: Leucas cephalotes/analgesic activity. Leucas cephalotes/antioxidant activity. Leucas cephalotes/anti-inflammatory activity. Diphenyl Picryl Hydrazyl assay.

O extrato metanólico total de Leucas cephalotes foi submetido à triagem para as atividades antioxidante in vitro (utilizando o método DPPH), analgésica (utilizando teste da placa quente, em camundongos) e antiinflamatória (utilizando teste de edema da pata de rato), nas doses de 200 e $400 \mathrm{mg} / \mathrm{kg}$. O extrato metanólico de Leucas cephalotes (MELC) inativou radicais difenil picril hidrazila (DPPH) de forma dose-dependente. $\mathrm{O} \mathrm{IC}_{50}$ para essa atividade foi de $421,3 \mu \mathrm{g} / \mathrm{mL}$. Observou-se atividade analgésica significativa (p<0,0005) a 60 minutos, com $200 \mathrm{mg} / \mathrm{kg}$, e, com $400 \mathrm{mg} / \mathrm{kg}$, observou-se atividade máxima. A resposta antiinflamatória máxima foi produzida, respectivamente, em $3 \mathrm{~h}$ e $2 \mathrm{~h}$, com doses de 200 e $400 \mathrm{mg} / \mathrm{kg}$. Estes resultados sugerem que o extrato metanólico de Leucas cephalotes apresenta efeitos analgésico e antiinflamatório significativos, comparáveis aos fármacos padrão.

Unitermos: Leucas cephalotes/atividade analgésica. Leucas cephalotes/atividade antioxidante. Leucas cephalotes/atividade antiinflamatória. Difenil Picril Hidrazila/análise.

\section{INTRODUCTION}

Leucas cephalotes (synonym: L. Capitata) is a herb of the family Labiatae and has been extensively used by rural people of Bihar, India (Kamat et al., 1994). The plant is also known as "Dronapushpi in Sanskrit and Peddatumni in telugu by Indians"(Parrotta et al., 2001). The whole plant was used to treat bronchitis, inflammation, asthma, dyspepsia, paralysis and skin diseases. The leaf

*Correspondence: G. K. Mohan. University College of Pharmaceutical Sciences, Kakatiya University, Warangal, INDIA-506009. E-mail: babupharma79@gmail.com juice is sometimes mixed with honey to treat coughs and colds among the Santhalis in southern Bihar and by rural inhabitants of Gujarat in India, where it is also used for treating jaundice (Kamat et al., 1994). The ethyl extract of whole plant of Leucas cephalotes has been reported for its protective effects on $\mathrm{CCl}_{4}$-induced hepatotoxicity in mice and rats (Singh et al., 1978). Nineteen compounds were isolated by chromatographic separation of 1-butanolsoluble fraction of the $\mathrm{MeOH}$ extract of Leucas cephalotes (Miyaichi et al., 2006). The structures of known compounds were identified as oleanolic acid, 7-oxysitisterol (Greca et al.,1990; Pettit et al.,1972), 7-oxostigmasterol (Katsui et al.,1972), 7 alpha-hydroxysitosterol (Greca et 
al., 1990), 7 alpha-hydroxystigmasterol (Miyaichi et al., 2006), stigmasterol (Kolak et al., 2005), 5-hydroxy-7, 4'-dimeathoxyflavone (Gonzalez et al.,1989), gonzalitosin (Dominguez et al., 1976), tricin (Fujii et al., 1995) and apigenin 7-0- $\beta$-D-(6-O-p-coumaroyl) glucopyranoside (Itokawa et al.,1981).The aim of the present study was to evaluate the In vitro anti-oxidant, In vivo analgesic and anti inflammatory activities of the methanolic whole plant extract of Leucas cephalotes (MELC).

\section{MATERIALS AND METHODS}

\section{Plant material}

The whole plant of L. cephalotes was collected from Kakatiya University, Warangal. The plant material was authenticated by Prof. V. S. Raju, Dept of Botany, Kakatiya University, Warangal, Andhara Pradesh, India.

\section{Preparation of extract}

The whole plant was cut into small pieces, shade dried and then ground into coarse powder $(2 \mathrm{~kg})$. The powder was then subjected to exhaustive extraction by a maceration process using methanol as a solvent at room temperature for 7 days. The methanolic extract was concentrated by vacuum distillation to dryness; the yield obtained was $7.5 \% \mathrm{w} / \mathrm{w}$ with respect to dried plant material. The collected extract was stored in a dessicator. A suspension of the extract prepared in $2 \%$ gum acacia was used in experimental studies.

\section{Drugs and chemicals}

The drugs and chemicals used were carrageenan, ascorbic acid (SD fine chemicals Limited, Mumbai), gum acacia and diclofenac sodium (Dr. Reddy's Labs, Hyderabad), pentazocine (Pure Pharma Ltd., Mumbai), methanol (Merck, Mumbai), DPPH (Sigma, USA).

\section{Animals}

Albino mice (25-30g) and Wistar rats (175-250 g) of both sexes were used for assessing biological activity. The animals were maintained under standard husbandry conditions and had free access to food and water ad libitum. The animals were allowed to acclimatize to the environment for 7 days prior to the experimental session. The animals were divided into different groups, each consisting of six animals which were fasted overnight prior to the experiments. Experiments on animals were performed in accor- dance with guidelines of the Institutional Animal Ethics Committee, UCPSc, Kakatiya University, Warangal, India.

\section{Phytochemical screening}

Phytochemical properties of the extract were tested using the following chemicals and reagents (Trease and Evans,1983): Alkaloids with Mayer and Dragendorff's reagents, saponins (frothing test), tannins $\left(\mathrm{FeCl}_{3}\right)$,glycosides ( $\mathrm{NaCl}$ and Fehling's solution $\mathrm{A}$ and $\mathrm{B})$, flavanoids $(\mathrm{NaCl}$ and $\mathrm{HCl}$ ), anthraquinones (Borntrager's reaction), phenols $\left(\mathrm{FeCl}_{3}\right.$ and $\left.\mathrm{K}_{3} \mathrm{Fe}(\mathrm{CN})_{6}\right)$, carbohydrates (Molisch's test) and lipids (filter paper).

\section{EXPERIMENTAL}

\section{Antioxidant activity}

\section{Diphenyl Picryl Hydrazyl (DPPH) method}

The free radical scavenging activity of MELC was measured by DPPH using the method of Blios (Blios et al.,1958). Ascorbic acid was used as a reference standard. The methanolic solution of DPPH $(0.2 \mathrm{mM})$ was added to different concentrations (100 to $800 \mu \mathrm{g} / \mathrm{ml}$ in methanol) of MELC solution. After $30 \mathrm{~min}$, absorbance was measured at $517 \mathrm{~nm}$. The degree of discoloration indicates the scavenging potential of the extract. Lower absorbance of the reaction mixture indicates higher free radical scavenging activity. The $\mathrm{IC}_{50}$ (Inhibitory Concentration) is the concentration of sample required to scavenge $50 \%$ of DPPH free radicals.

\section{Analgesic activity}

\section{Hot-Plate method}

The hot plate test was used to measure analgesic activity by the method described by Eddy and Leimback (Eddy et al., 1953) with minor modifications. In this experiment, the hot plate was maintained at $55 \pm 0.5^{\circ} \mathrm{C}$. All animals were selected $24 \mathrm{hr}$ prior to experimentation on the basis of their normal reaction time i.e., pain response to the hot plate to the minimum and maximum of $2-15 \mathrm{sec}$, respectively. In order to avoid damaging the paws of the animals, the time standing on the plate was limited to 25 sec. Pentazocine $10 \mathrm{mg} / \mathrm{kg}$ was administered intraperitoneally as a reference standard. Thirty minutes after administration of vehicle ( $2 \%$ gum acacia, p.o.) / methanolic extract (200 and $400 \mathrm{mg} / \mathrm{kg}$, p.o.) /standard drug, animals were placed individually onto the hot plate and the time from placing the animal on the hot plate to jumping of the animal from the hot plate was recorded as the reaction time 
or latency of the pain response.

\section{Anti-inflammatory activity}

\section{Carrageenan-induced oedema test}

The normal paw volumes of all the rats were measured initially and then divided into four groups each comprising six animals, treated orally with the vehicle as controls ( $2 \%$ gum acacia, p.o.), with standard diclofenac sodium $(20 \mathrm{mg} / \mathrm{kg}$, p.o.), and with methanolic extract (200 and $400 \mathrm{mg} / \mathrm{kg}$, p.o.), respectively. Carrageenan (0.1 $\mathrm{ml}$ of a $1 \%$ suspension in saline) was injected into the sub-plantar region of the right hind paw of each rat. The vehicle, drug and extract were administered $30 \mathrm{~min}$ prior to the injection of Carrageenan. The paw volumes of all the rats were recorded at 1, 2, 3 and $4 \mathrm{hr}$ after Carrageenan treatment by using a plethysmometer (Turner, 1965). A significant reduction in paw volume compared to vehicletreated control animals was considered an inflammatory response.

$\%$ Inhibition $=\left[\left(\mathrm{V}_{\mathrm{T}}-\mathrm{V}_{0}\right)\right.$ control $-\left(\mathrm{V}_{\mathrm{T}}-\mathrm{V}_{0}\right)$ treated groups] / $\left(\mathrm{V}_{\mathrm{T}}-\mathrm{V}_{0}\right)$ control $* 100$

$\mathrm{V}_{0}=$ paw volume of the rat before administration of Carrageenan

$\mathrm{V}_{\mathrm{T}}=$ paw volume of the rat after administration of Carrageenan at different time intervals

\section{Statistical analysis}

All the results were expressed as mean $\pm \mathrm{SD}$ and analyzed by one way ANOVA followed by Dunnet's test, and $\mathrm{P}<0.05$ was considered statistically significant.

\section{RESULTS AND DISCUSSION}

\section{Phytochemical analysis}

Steroids, phenols, terpenoids, carbohydrates and glycosides were identified by preliminary phytochemical tests.

\section{Antioxidant activity}

In the present study, DPPH radical was used as a substrate to evaluate the free radical scavenging activity of MELC extract. The reduction capability of DPPH radicals was determined by the decrease in its absorbance at 517 $\mathrm{nm}$, which is induced by antioxidants. Hence, DPPH is often used as a substrate to evaluate antioxidant activity of MELC extract. The DPPH scavenging property of MELC is shown in Figure 1. The $\mathrm{IC}_{50}$ value of the extract was found to be $421.3 \mu \mathrm{g} / \mathrm{ml}$, which was significantly higher than that of standard antioxidant ascorbic acid $(50 \mu \mathrm{M})$. This indicates the lower in vitro free radical scavenging capacity (antioxidant activity) of MELC compared to ascorbic acid.

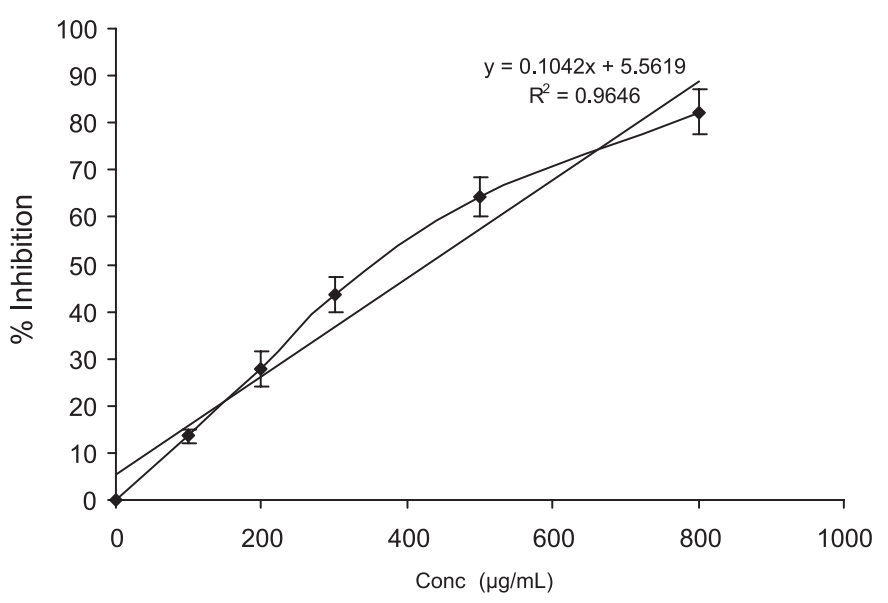

FIGURE 1 - In vitro Antioxidant activity of MELC using DPPH method.

Plants produce a variety of antioxidants against molecular damage from reactive oxygen species [ROS], produced by macrophages. Phenolic compounds are the major class of plant-derived antioxidants. Among the various phenolic compounds, flavonoids are perhaps the most important group (Kuo et al., 1992). In the present study, the antioxidant activity of $L$. cephalotes might be due to the presence of flavonoids such as 5-hydroxy 7 , $4^{1}$-dimeathoxyflavone, pillion, gonzalitosin, and tricin, in the methanolic extract.

\section{Analgesic and anti-inflammatory activity}

The results of the hot-plate method for analgesic activity and of the rat paw edema method for anti inflammatory activity, of methanolic extract of $L$. cephalotes are shown in Tables 1 and 2. A significant $(\mathrm{p}<0.0005)$ analgesic effect was observed at $60 \mathrm{~min}$ with $200 \mathrm{mg} / \mathrm{kg}$ of L. cephalotes. Higher doses i.e. $400 \mathrm{mg} / \mathrm{kg}$ of methanolic extract, exhibited the highest analgesic effect in response to the thermal stimulus at $120 \mathrm{~min}$, where this was comparable to the effect of standard pentazocine.

After Carrageenan administration, paw edema in rats reached a peak value at $3 \mathrm{hr}$ and the maximum anti-inflammatory response (inhibition of Carrageenan-induced paw volume) was produced at $3 \mathrm{hr}$ and $2 \mathrm{hr}$ with doses of 200 and $400 \mathrm{mg} / \mathrm{kg}$, respectively.

In conclusion, the methanolic extract of $L$. cephalotes exhibited significant antioxidant, analgesic and anti inflam- 
TABLE I - Effect of methanolic extract from L. cephalotes on the hot plate test in mice

\begin{tabular}{|c|c|c|c|c|c|c|}
\hline \multirow[t]{2}{*}{ S.No } & \multirow[t]{2}{*}{ Group } & \multirow{2}{*}{$\begin{array}{c}\text { Dose } \\
(\mathrm{mg} / \mathrm{kg})\end{array}$} & \multicolumn{4}{|c|}{ Reaction time after administration of control/standard/ extract in sec } \\
\hline & & & $0 \mathrm{~min}$ & $60 \mathrm{~min}$ & $120 \mathrm{~min}$ & $240 \mathrm{~min}$ \\
\hline 1. & Control & & $2.17 \pm 0.75$ & $2.33 \pm 0.52$ & $2.17 \pm 0.41$ & $1.67 \pm 0.52$ \\
\hline 2. & Pentazocine & 10 & $2.83 \pm 0.75$ & $6.83 \pm 0.75^{\mathrm{c}}$ & $6.33 \pm 1.63^{b}$ & $2.33 \pm 0.52^{\mathrm{a}}$ \\
\hline 3. & L. cephalotes & 200 & $2.67 \pm 0.82$ & $7.33 \pm 1.03^{\mathrm{c}}$ & $8.00 \pm 1.10^{\mathrm{c}}$ & $2.00 \pm 0.63$ \\
\hline 4. & L. cephalotes & 400 & $2.83 \pm 0.75$ & $8.17 \pm 1.17^{\mathrm{c}}$ & $9.17 \pm 0.75^{\mathrm{c}}$ & $2.17 \pm 0.75$ \\
\hline
\end{tabular}

Values are expressed as mean $\pm \mathrm{SD} ;(\mathrm{n}=6), \mathrm{a}=\mathrm{p}<0.05, \mathrm{~b}=\mathrm{p}<0.005, \mathrm{c}=\mathrm{P}<0.0005$ Vs Control.

TABLE II - Effect of methanolic extract from L. cephalotes on the paw edema test in rats

\begin{tabular}{|c|c|c|c|c|c|c|}
\hline \multirow[t]{2}{*}{ S. No } & \multirow[t]{2}{*}{ Group } & \multirow[t]{2}{*}{ Dose $(\mathrm{mg} / \mathrm{kg})$} & \multicolumn{4}{|c|}{ Paw edema volume after } \\
\hline & & & $1 \mathrm{hr}$ & $2 \mathrm{hr}$ & $3 \mathrm{hr}$ & $4 \mathrm{hr}$ \\
\hline 1. & Control & & $0.18 \pm 0.02$ & $0.20 \pm 0.03$ & $0.22 \pm 0.03$ & $0.18 \pm 0.02$ \\
\hline 2. & Diclofenac Sodium & 20 & $0.14 \pm 0.02^{\mathrm{a}}$ & $0.13 \pm 0.02^{\mathrm{c}}$ & $0.12 \pm 0.02^{c}$ & $0.12 \pm 0.02^{\mathrm{c}}$ \\
\hline 3. & L. cephalotes & 200 & $0.15 \pm 0.01^{\mathrm{a}}$ & $0.14 \pm 0.01^{\mathrm{b}}$ & $0.13 \pm 0.02^{\mathrm{c}}$ & $0.14 \pm 0.02^{\mathrm{a}}$ \\
\hline 4. & L. cephalotes & 400 & $0.14 \pm 0.01^{\mathrm{a}}$ & $0.12 \pm 0.01^{\mathrm{c}}$ & $0.12 \pm 0.02^{\mathrm{c}}$ & $0.13 \pm 0.03^{\mathrm{a}}$ \\
\hline
\end{tabular}

Values are expressed as mean $\pm \mathrm{SD} ;(\mathrm{n}=6), \mathrm{a}=\mathrm{p}<0.05, \mathrm{~b}=\mathrm{p}<0.001, \mathrm{c}=\mathrm{p}<0.005$ Vs Control.

matory activity. Further studies are needed for fractionation and purification of the compounds present in the methanolic extract of $L$. cephalotes to identify the chemicals responsible for the biological activities outlined above.

\section{REFERENCES}

BLIOS, M. S. Antioxidant determination by the use of stable free radical. Nature, v.26, p.1199, 1958.

DOMINGUEZ, X. A.; HINOJOSA, M. Isolation of 5-hydroxy7,3',4'-trimethoxy-flavone from Turnera diffusa. Planta Medica, v.30, p.68-71, 1976.

EDDY, N. B; LEIMBACH, D. Synthetic analgesics: II. Dithienylbutenyl and dithienylbutylamines. J. Pharmacol. Exp. Ther., v.107, p.385-393, 1953.

FUJII, M.; MIYAICHI, Y.; TOMIMORI, T. Flavonoid, phenylethanoid and iridoid constituents of the whole plant of Pedicularis longiflora var. tubiformis. Planta Medica, v.61, p.584-586, 1995.

GONZALEZ,A. G.; AGUIAR, Z. E.; LUIS, J. G.; RAVELO, A. G.; VAZQUEZ, J. T.; DOMINGUEZ, X. A. Flavonoids from Salvia texana. Phytochemistry, v.28, p.2871-2872, 1989.
GRECA, M. D.; MONACO, P.; PREVITERA, L. Stigmasterol from Typha latifólia. J. Nat. Prod., v.53, p.1430-1435,1990.

ITOKAWA, H.; SUTO, K.; TAKEYA, K. Studies on a novel p-coumaroyl glucoside of Apigenin and on other flavonoids isolated from Patchouli (Labiatae). Chem. Pharm. Bull., v.29, p.254-256, 1981.

KAMAT, M.; SINGH, T. P. Preliminary chemical examination of some compounds in different parts of the genus Leucas. Geobios., v.21, p.31-33,1994.

KATSUI, N.; MATSUE, H.; HIRATA, T.; MASAMUNE, T. Phytosterols and triterpenes in the roots of the "kidney bean" (Phaseolus vulgaris L.) Bull. Chem. Soc. Jpn., v.45, p.223-226,1972.

KUO, S. D.; SHANKEL, M.; TELIKEPALLI, H. Glycyrrhiza glabra extract as an effector of interception in Escherichia coli K12. Mut. Res., v.282, p.93-98, 1992.

PARROTTA, J. A. Healing plants of peninsular India. New Delhi: CABI publishing, 2001. p.436-437. 
PETTIT, G.R.; NUMATA, A.; CRAGG, G. M.; HERALD, D. L.; TAKADA, T.; IWAMOTO, C.; RIESEN, R.; SCHMIDT, J. M.; DOUBEK, D. L.; GOSWAMI, A. Isolation and structures of Schleicherastatins 1-7 and Schleicheols $1 \& 2$ from the teak forest medicinal tree Schleichera oleosa. J. Nat. Prod., v.63, p.72-78, 2000.

SINGH, N.; NATH, R.; GUPTA, M.L.; KOHLI, R.P. An experimental evaluation of protective effects of some indigenous drugs on carbon tetrachloride-induced hepatotoxicity in mice and rats. Q. J. Crude Drug Res., v.16, p.8-16, 1978.

TREASE, G.E.; EVANS, M.C. Text book of pharmacognosy. 12.ed. London: Balliere Tindall Press, 1983. p.309-539.
TURNER, R.A. Screening methods in pharmacology. New York: Academic Press, 1965. p.22.

KOLAK, U.; GULAÇTI, T.; SEHER, B.; GÜLTEN, O.; AYHAN, U. Terpenoids and steroids from the roots of Salvia blepharochlaena. Turk. J. Chem., v.29, p.177-186, 2005.

MIYAICHI, Y.; SEGAWA, A.; TOMIMORI, T. Studies on nepalese crude drugs. XXIX. Chemical constituents of Dronapuspi, the whole herb of Leucas cephalotes Spreng. Chem. Pharm. Bull., v.54, p.1370-1379, 2006.

Received for publication on $23^{\text {rd }}$ June 2009 Accepted for publication on $11^{\text {th }}$ February 2010 